WAYNE HOPE is an associate professor in the School of Communication Studies, AUT University.

\section{A stirring parade of political villains}

No Left Turn: The distortion of New Zealand's history by greed, bigotry and right-wing politics, by Chris Trotter. Auckland: Random House, 2007. 384pp. ISBN 9781869418090

$\Upsilon$ HE mid-1980s was a turning point in New Zealand's economic and political history. Under the fourth Labour government the corporate sector was convulsed by finance driven takeover activity. Finance Minister Roger Douglas, other senior cabinet ministers, Treasury and the Reserve Bank unleashed a far reaching new right policy agenda favourable to corporate and financial interests. Banking and finance were deregulated, the New Zealand dollar was floated and a goods and services tax introduced. Meanwhile state energy, telecommunications and railway infrastructures were

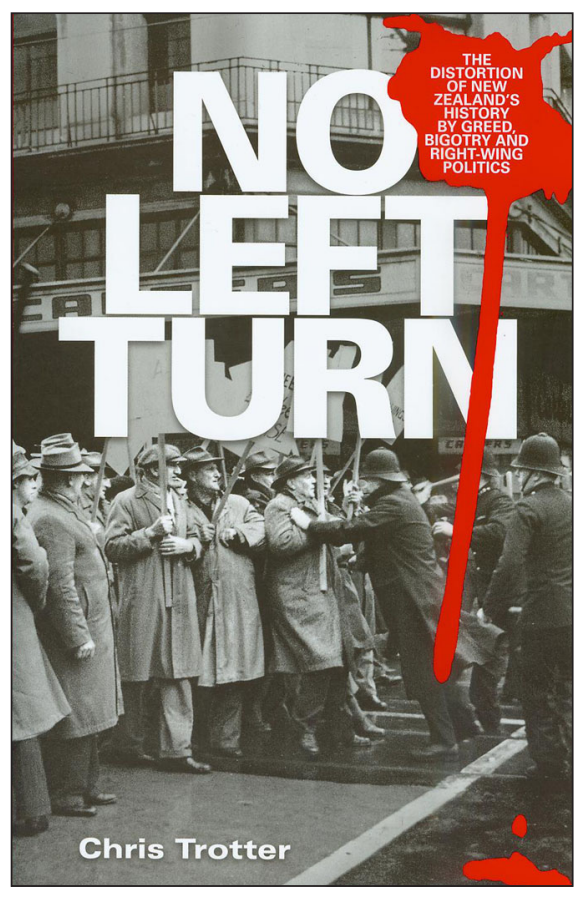

corporatised and, subsequently, sold to private corporations.

The magnitude of these changes enabled business leaders, governing elites and compliant journalists to rewrite history. New Zealand had been, apparently, a decrepit, overregulated economy; a Polish shipyard with insufficient restaurants and poor coffee. This stark recollection, tempered by a condescending wistfulness for 'old' New Zealand, became embedded within popular culture.

From Te Papa Museum to the Holmes Show modern history was mulched into nostalgia for the 'golden 
years' and the 'way we were'. The net result has been amnesia. Beyond academia, public debate about New Zealand's history has been intermittent at best.

Against this background, Chris Trotter's No Left Turn is a passionate attempt to stir up historical argument and cause political trouble. Accordingly, the book's frontpiece subtitle, 'the distortion of New Zealand's history by greed, bigotry and right wing politics' is superimposed upon a long, blood red droplet. Underneath, is a cover photo of a 1950s street confrontation between protesting workers and baton wielding police.

Over subsequent chapters, Trotter explains how key phases of New Zealand history were shaped by institutionalised power and political struggle. Along the way major villains are identified, paraded and held to account. During the colonisation phase we observe how Edward Wakefield's land speculation schemes overruled the customary rights of Maori and exploited the aspirations of lowly settlers. Similarly, Thomas Russell, commercial lawyer and founder of the Bank of New Zealand is vilified for on-selling confiscated Maori land to settlers and legalising the process.

During the late 1880s and 1890s urban workers, manufacturers, small traders and small farmers combined to elect a succession of Liberal Reform governments. Their long term achievements were the introduction of a modern pastoral economy and the inauguration of a full, citizenbased franchise.

Consequently, previously excluded economic and social perspectives began to inform government policy. A raft of labour and social reform legislation signified the beginnings of a welfare state and industrial relations system. Trotter outlines these developments and traces the subsequent emergence of class-based unionism in New Zealand.

During the early 1900s as real wages declined, worker militancy rose, especially among miners and watersiders. With characteristic verve, Trotter recounts the rise of the Red Federation led and/or supported by the likes of Paddy Webb, Pat Hickey, Peter Fraser, Bob Semple and Harry Holland (eventual founding leader of the New Zealand Labour Party). The class interests at stake in the Waihi miner strike of 1912 and the great strike of 1913 are well described, as are the confrontations involving protesting workers, police and vigilante farmers.

From here, Trotter lays out an oppositional version of early to mid20 th century New Zealand politics. In 
his chronology of tales we learn how World War One turned New Zealand soldiers into Imperial cannon folder, despite local resistance to the draft, how conservative politicians closed down popular, dissenting voices during the great depression and how the first Labour government founded a modern social democratic political economy upon agriculture, import protected manufacturing, credit creation, infrastructural development, full employment and welfare provision.

In emphasising the progressive nature of these latter accomplishments, Trotter undercuts the familiar New Right retrospective of burgeoning regulation and declining economic freedom. Although this critical task has already been performed by left political economists and historians it needs repeating for a popular readership. The same can be said of the 1950s, a decade much rebuked for its Cold War hysteria.

At the time of writing, one reactionary New Zealand journalist has labelled a certain long-deceased scholar-diplomat along with a former, prominent civil servant as Soviet spies without supporting evidence. Nowadays, McCarthyism is a retro curiosity. However, as Trotter reminds us, it was once official doctrine.

During the 1951 waterfront lockout, Sydney Holland's National government, the mainstream media and the Federation of Labour ex-communicated dissident union leaders. At this point one could argue, from a left perspective, that New Zealand was indeed a state-regulated society; antistrike legislation allowed the government to arrest citizens and search property without warrant, prohibit public meetings, censor publications and prosecute anybody offering food to strikers.

Meanwhile, better off $\mathrm{New}$ Zealanders entered a safe world of suburbanising materialism centred around private property, motorways and the automobile. In a fascinating chapter entitled 'The Auckland that never was', Trotter argues that another future was possible.

Drawing upon the urban history research of Chris Harris Trotter reveals how a small group of émigre visionaries in the Ministry of Works and the Department of Housing fashioned a detailed blueprint for greater Auckland premised upon the development of public housing and public transport corridors. Their vision was extinguished by a right-leaning Labour government from 1946 to 1949 and by the McCarthyite National government of 1951. Thus, New Zealand's largest city became what it is today; a low density, suburban dystopia of traffic jams, shopping 
malls and real estate speculation.

The following chapter, 'Savage's children' has less analytical focus. Capitalist restructuring, party politics and union struggle are intermingled with the emergence of new social movements focused upon the environment, nuclear proliferation, apartheid South Africa and United States imperialism. Trotter recalls these tumultuous times without asking the central question; were labour-left ideals reconciliable with those of the new social movements?

In this respect the growing Maori struggle for the reparation of land, language and culture deserved special consideration.Under a new generation of leadership tribal, urban-based and nationwide forums rejected the 'colony to nation' story as a distortion of history. Here, one should ask: to what extent is this perspective compatible with a left-labour reconstruction of the national past?

Over the final two chapters the causes and consequences of the new right policy agenda are well considered. Trotter knows this territory well, as a former political activist with the breakaway New Labour Party and as a partisan journalist. He also draws skilfully from the writings of Hugh Oliver, Brian Roper and Bruce Jesson to illustrate the collusions of interest among corporate, public servant and political elites. This case could have been strengthened further with reference to Jane Kelsey`s work on state restructuring, globalisation and 'third way' politics.

Trotter's epilogue contains a summary tirade against the purveyors of 'economic exploitation and social injustice'. In effect, New Zealand villains of the 19th and early to mid-20th century are lined up with their New Right descendants. Thus, Edward Wakefield stands alongside Ruth Richardson (New Zealand's Far Right finance minister 199091). Contemporary problems of political agency and coalition building within a branch economy are left unaddressed.

Then again, with the parade of villains on display, a more enjoyable task presents itself. Let's all give them a good kicking. 